\section{DENDRITIC CELLS}

\section{IRF2 directs cell distinction}

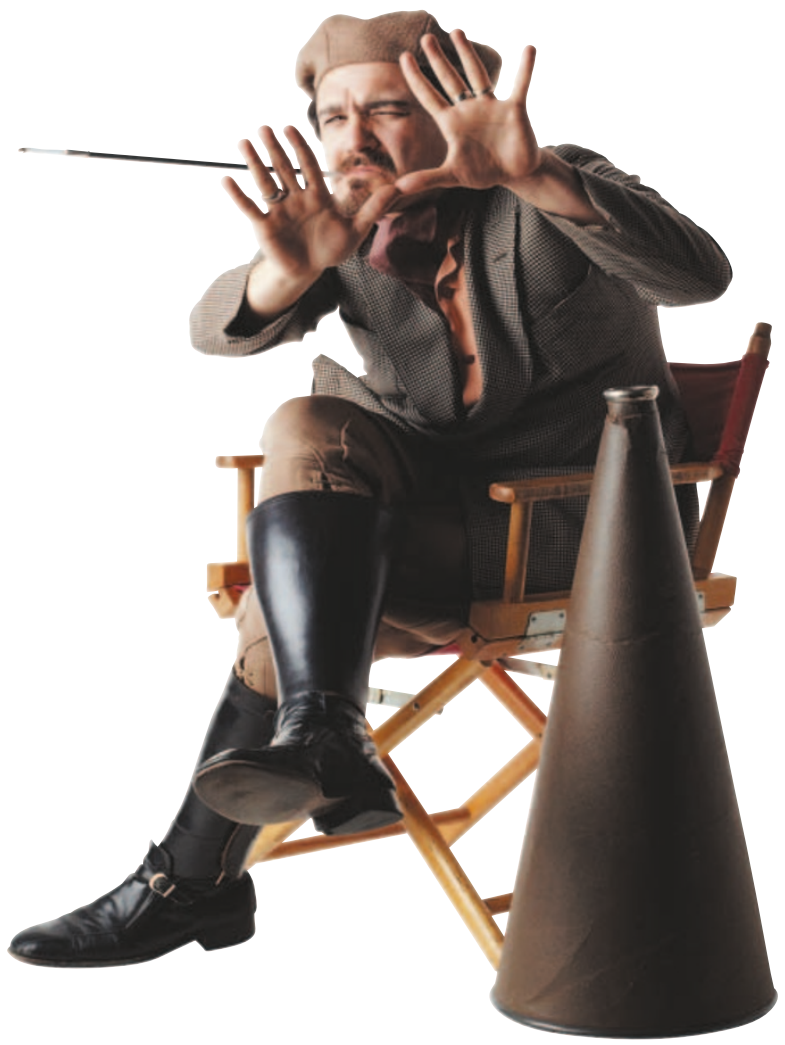

Despite the identification of distinct subsets of dendritic cells (DCs), as defined by their expression of a combination of cell-surface markers such as $\mathrm{CD} 11 \mathrm{~b}, \mathrm{CD} 11 \mathrm{c}, \mathrm{CD} 8 \alpha$ and $\mathrm{CD} 4$, little is known about the molecular mechanisms that differentially regulate their development. Now, Shinsuke Taki's group has shown that the transcription factor interferon regulatory factor 2 (IRF2) is crucial for the development of splenic and epidermal $\mathrm{CD} 4^{+}$DCs. This study is consistent with a previous report from Tadatsugu Taniguchi's laboratory showing that IRF2 is required for the development of CD8 $\alpha^{-} \mathrm{CD} 11 \mathrm{~b}^{+} \mathrm{CD} 11 \mathrm{c}^{+}$DCs.

Analysis of DC subsets in Irf2deficient mice showed a marked decrease in the number of $\mathrm{CD} 4^{+}$ CD $11 b^{+}$DCs in the spleen, as compared with wild-type animals. By contrast, other DC subsets were present at normal frequencies or, in the case of $\mathrm{CD} 8 \alpha^{+} \mathrm{CD} 11 \mathrm{~b}^{-} \mathrm{DCs}$, at slightly increased numbers. Further examination showed that in the epidermis of the Irf2-deficient mice, the subset of

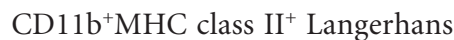
cells (LCs) expressing cytoplasmic CD4 was severely depleted.
By generating reciprocal bonemarrow (BM) chimaeras, it was shown that the reduction in splenic $\mathrm{CD} 4{ }^{+} \mathrm{CD} 11 \mathrm{~b}^{+} \mathrm{DC}$ numbers was a result of Irf2 deficiency in BMderived progenitor cells. This cellautonomous role for Irf2 was also observed in BMDCs: fewer CD11 $\mathrm{b}^{+}$ $\mathrm{CD} 11 \mathrm{c}^{+} \mathrm{DCs}$ were generated after in vitro culture of Irf2-deficient BM cells than wild-type BM cells. In addition, BMDCs from Irf2-deficient mice were less mature and did not fully upregulate the expression of CD40 or CD86 after stimulation with lipopolysaccharide (LPS) or unmethylated CpG DNA, indicating a role for Irf2 in the maturation of DCs, at least in vitro. However, the requirement for Irf2 in BMDC maturation is not absolute, as the levels of cytokines produced by LPSand CpG-stimulated Irf2-deficient BMDCs were indistinguishable from those produced by similarly treated wild-type BMDCs.

Irf2 has previously been shown to attenuate signals induced by interferon- $\alpha$ (IFN- $\alpha)$ and IFN- $\beta$. The numbers of splenic $\mathrm{CD} 4^{+} \mathrm{CD} 11 \mathrm{~b}^{+}$ DCs and epidermal LCs expressing

\title{
REGULATORY T CELLS
}

\section{Reduction in regulation}

Selective depletion of the $\mathrm{CD} 4^{+} \mathrm{CD} 25^{+}$ regulatory $\mathrm{T}\left(\mathrm{T}_{\mathrm{Reg}}\right)$-cell subset in mice induces the spontaneous onset of autoimmune diseases. However, although human $\mathrm{CD} 4{ }^{+} \mathrm{CD} 25^{\mathrm{hi}} \mathrm{T}$ cells can elicit suppressive functions in vitro, there was little evidence of a role for these cells in vivo, until a study by Viglietta et al. showed that $\mathrm{CD} 4^{+} \mathrm{CD} 25^{\text {hi }}$ T cells in patients with multiple sclerosis (MS) have defective regulatory function. It is easier to activate autoreactive $T$ cells isolated from patients with autoimmune diseases than those from healthy controls. So, the authors set out to compare $\mathrm{CD} 4^{+} \mathrm{CD} 25^{\text {hi }} \mathrm{T}_{\mathrm{Reg}}$ cells isolated from untreated patients with relapsing/remitting MS and healthy control individuals. Initial analyses indicated no difference between the two groups in the level of expression of CD25, or in the frequency of $\mathrm{CD} 4{ }^{+} \mathrm{CD} 25^{+}$or $\mathrm{CD} 4^{+} \mathrm{CD} 25^{\text {hi }} \mathrm{T}$ cells in the blood. By contrast, when compared with $\mathrm{CD} 4^{+} \mathrm{CD} 25^{\mathrm{hi}} \mathrm{T}_{\mathrm{Reg}}$ cells purified from healthy controls, $\mathrm{CD} 4^{+} \mathrm{CD} 25^{\text {hi }}$ $\mathrm{T}_{\mathrm{Reg}}$ cells isolated from MS patients were markedly impaired in their ability to suppress $\mathrm{CD}^{+}{ }^{+} \mathrm{CD} 25^{-} \mathrm{T}$-cell proliferation and interferon- $\gamma$ production induced by platebound CD3-specific antibody. This lack of suppression resulted from a loss of regulatory function by the $\mathrm{CD} 4^{+} \mathrm{CD} 25^{\text {hi }} \mathrm{T}$ cells and not a defect in the $\mathrm{CD} 4^{+} \mathrm{CD} 25^{-} \mathrm{T}$ cells, as $\mathrm{CD} 4{ }^{+} \mathrm{CD} 25^{\text {hi }} \mathrm{T}_{\text {Reg }}$ cells from healthy individuals were able to suppress autologous $\mathrm{CD} 4{ }^{+} \mathrm{CD} 25^{-} \mathrm{T}$ cells and those derived from MS patients equally. In reciprocal studies, the $\mathrm{CD} 4^{+} \mathrm{CD} 25^{\text {hi }} \mathrm{T}_{\text {Reg }}$ cells from MS patients could not suppress proliferation of $\mathrm{CD} 4^{+} \mathrm{CD} 25^{-}$ $T$ cells from either healthy individuals or MS patients.

The $\mathrm{CD} 4^{+} \mathrm{CD} 25^{\mathrm{hi}} \mathrm{T}_{\mathrm{Reg}}$-cell population in MS patients was shown not to be diluted by recently activated cells involved in the ongoing MS-associated immune response in three ways. First, $\mathrm{CD} 4{ }^{+} \mathrm{CD} 25^{\text {hi }} \mathrm{T}$ cells in both
MS patients and healthy individuals were anergic; second, the $\mathrm{CD} 4{ }^{+} \mathrm{CD} 25^{\mathrm{hi}} \mathrm{CD} 62 \mathrm{~L}^{+}$ cells, which contain no potentially activated CD62 $\mathrm{L}^{-} \mathrm{T}$ cells, from MS patients were unable to inhibit $\mathrm{CD} 4^{+} \mathrm{CD} 25^{-} \mathrm{T}$-cell proliferation; and third, $\mathrm{CD} 4^{+} \mathrm{CD} 25^{\text {hi }} \mathrm{T}$ cells isolated from a healthy individual before and after vaccination against influenza virus to induce an ongoing immune response were equally capable of suppressing $\mathrm{CD}^{+} \mathrm{CD} 25^{-} \mathrm{T}$-cell proliferation.

These data provide the first evidence that a defect in $\mathrm{CD} 4{ }^{+} \mathrm{CD} 25^{\text {hi }} \mathrm{T}_{\mathrm{Reg}}$-cell function can be linked to an autoimmune disease in humans. Further work is needed to determine whether such dysregulation can be viewed as a risk factor for autoimmunity. However, the authors' initial studies showing that $\mathrm{CD} 4{ }^{+} \mathrm{CD} 25^{\text {hi }} \mathrm{T}$ cells from patients with thyroiditis and psoriasis have reduced regulatory function indicate that this hypothesis might hold up.

Karen Honey

(2) References and links

ORIGINAL RESEARCH PAPER Viglietta, V. et al. Loss of functional suppression by $\mathrm{CD} 4^{+} \mathrm{CD} 25^{+}$regulatory $T$ cells in patients with multiple sclerosis. J. Exp. Med. 199, 971-979 (2004) 
cytoplasmic CD4 detected in mice deficient in both Irf2 and IFN- $\alpha / \beta$ receptor 1 were comparable to those found in littermate controls, indicating that the role of Irf2 in regulating the development of these DC subsets was to attenuate type 1 IFN-induced signals.

This report confirms the previous study identifying Irf2 as a molecular regulator of a specific DC subset, namely that characterized as $\mathrm{CD} 4^{+}$ $\mathrm{CD}_{11} \mathrm{~b}^{+}$or $\mathrm{CD} 8 \alpha^{-} \mathrm{CD} 11 \mathrm{~b}^{+} \mathrm{CD} 11 \mathrm{c}^{+}$. Combined with other studies indicating a crucial role for Irf8 in the development of CD8 $\alpha^{+}$DCs and plasmacytoid DCs, these data begin to provide insight into the distinct molecular pathways responsible for the differentiation of discrete DC subsets.

\section{Karen Honey}

(Q) References and links ORIGINAL RESEARCH PAPER Ichikawa, E. et al. Defective development of splenic and epidermal $\mathrm{CD} 4^{+}$dendritic cells in mice deficient for IFN regulatory factor-2. Proc. Natt Acad. Sci. USA 101, 3909-3914 (2004)

FURTHER READING Honda, K., Mizutani, T. \& Taniguchi, T. Negative regulation of IFN- $\alpha / \beta$ signaling by IFN regulatory factor 2 for homeostatic development of dendritic cells. Proc. Natl Acad. Sci. USA 101, 2416-2421 (2004)

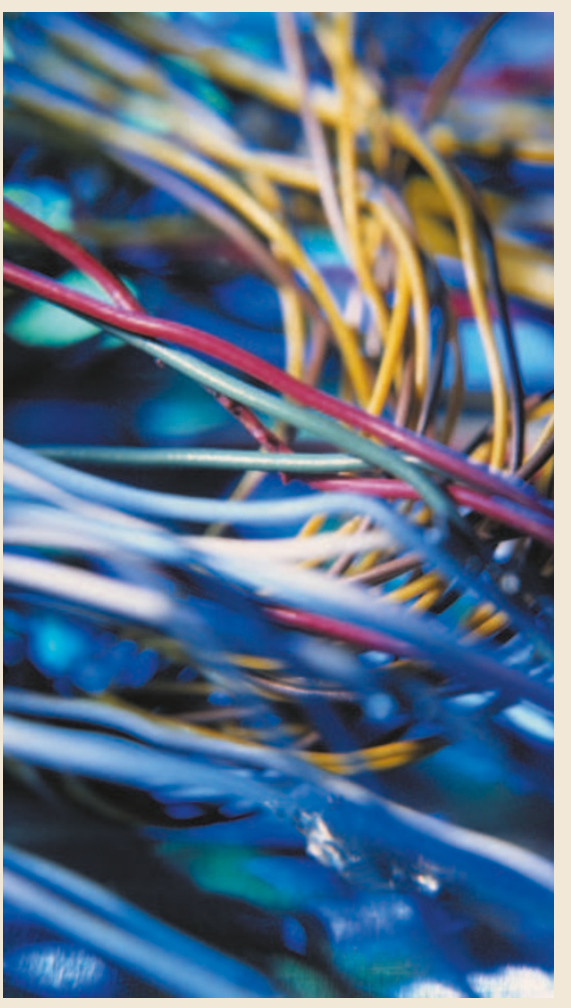

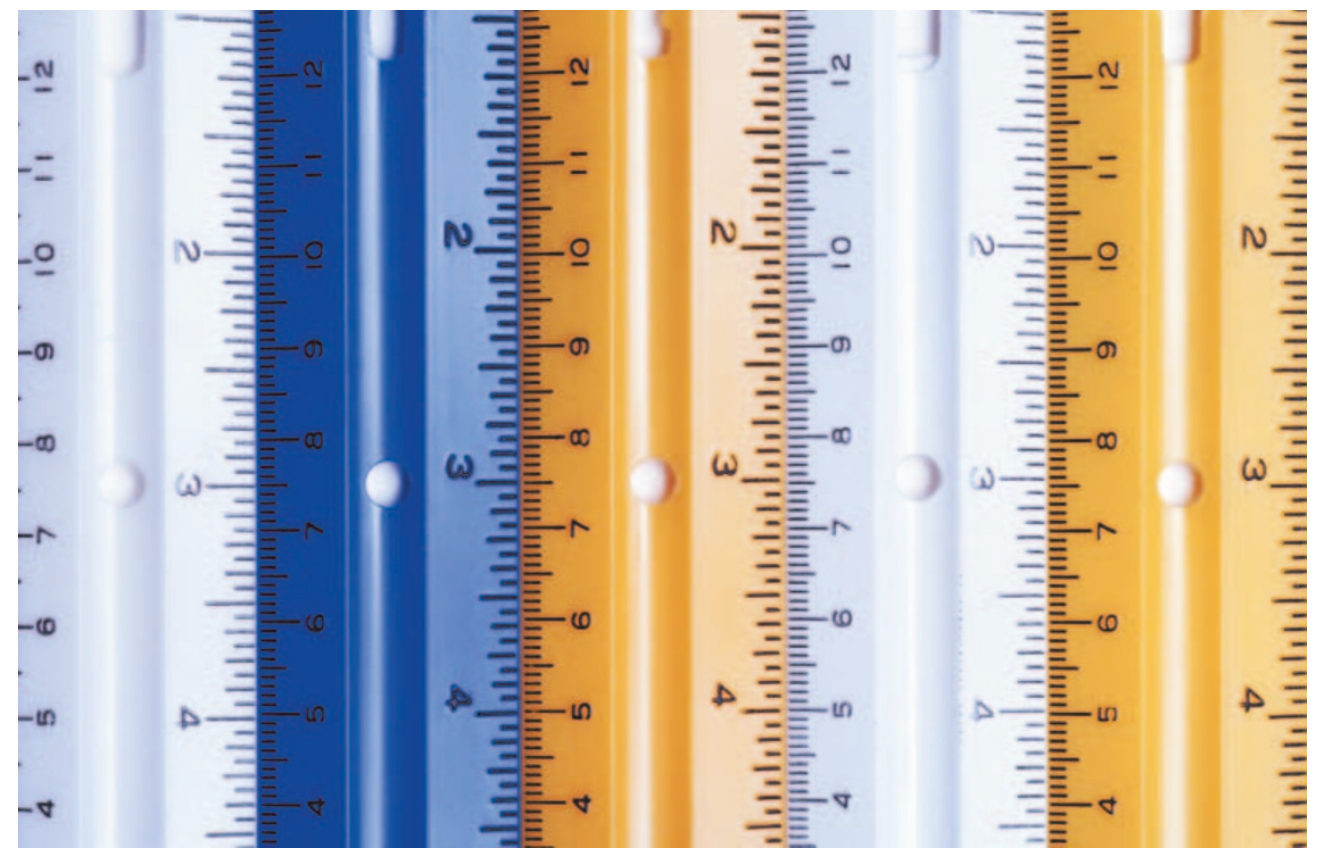

\section{MAST CELLS}

\section{Size does matter}

It seems that mast cells haven't heard the familiar adage 'quality not quantity' - a new study published in Blood shows that their responses are based on the strength rather than type of stimulation. Depending on the amount of $\operatorname{IgE}$ with which the mast cell comes into contact and the duration of the interaction, crosslinking of FcERI can induce mast-cell degranulation or survival.

IgE bound to multivalent antigen $[\operatorname{IgE}(+\mathrm{Ag})]$ crosslinks Fc\&RI on the surface of mast cells, resulting in degranulation and the release of allergic mediators such as histamine. However, researchers have also shown that IgE in the absence of antigen $[\operatorname{IgE}(-\mathrm{Ag})]$ can induce cell survival without degranulation. As the degranulation and survival responses both rely on signalling through the common $\gamma$-subunits (FcR $\gamma$ ) of FceRI, Saito and colleagues set out to determine the importance of strength of signalling for the differential responses.

They transfected bone-marrow-derived mast cells (BMMCs) from FcR $\gamma$-deficient mice with a construct encoding a chimeric molecule consisting of the cytoplasmic domain of mouse FcR $\gamma$ linked to the extracellular and transmembrane domains of mouse CD8 $\alpha$. The strength of signalling through FcR $\gamma$ could then be altered using different concentrations of a CD8-specific antibody. Whereas high levels of antibody were necessary for degranulation, increased survival resulted from stimulation with both low and high concentrations of CD8-specific antibody.

To confirm that the signalling threshold for survival is lower than that for degranulation, the authors also looked at the effects of receptor valency. CD8 $\alpha$ normally dimerizes through a disulphide bond between its extracellular domains, so that the chimeric $\operatorname{CD} 8 \alpha-\mathrm{FcR} \gamma$ construct exists as a homodimer. When the crucial cysteine residues of $\mathrm{CD} 8 \alpha$ were mutated to prevent dimerization, mast cells had a similar survival response to treatment with CD8-specific antibody, but signalling through the monovalent receptor did not induce degranulation even in response to high concentrations of antibody.

In other cell types, activation of extracellularsignal-regulated kinase (Erk) is known to induce cell survival, and in this system, both high and low concentrations of CD8-specific antibody induced Erk activation. Also, introduction of an active form of the kinase Mek into the BMMCs, which directly activates Erk, increased cell viability, confirming the link between survival and Erk activation in mast cells.

However, in contrast to this artificial system in which degranulation and increased survival can occur together, in wild-type mast cells, $\operatorname{IgE}(-\mathrm{Ag})$ increases cell survival, whereas $\operatorname{IgE}(+\mathrm{Ag})$ induces degranulation in the absence of cell survival. Previous studies have shown that $\operatorname{IgE}(-\mathrm{Ag})$ elicits more prolonged Erk activation than $\operatorname{IgE}(+\mathrm{Ag})$, so the authors suggest that sustained Erk activity is necessary for survival. When the CD8-specific antibody was crosslinked with another antibody (mimicking IgE crosslinked with multivalent antigen), the initial Erk activation decreased rapidly due to receptor internalization, and the viability of these cells was significantly lower than cells treated only with the CD8-specific antibody. Mast cells treated with $\operatorname{IgE}(+$ immobilized Ag), which does not cause FceRI internalization, both degranulated and survived for longer.

Therefore, signals through FcR $\gamma$ can induce both degranulation and survival according to signal strength and duration, respectively.

Kirsty Minton

8) References and links

ORIGINAL RESEARCH PAPER Yamasaki, S. et al. The quantity and duration of FCR $\gamma$ signals determine mast cell degranulation and survival. Blood 103, 3093-3101 (2004) 